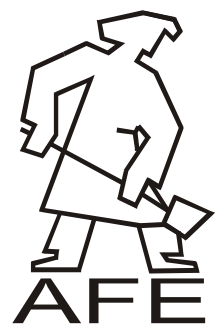

\title{
The Influence of Glassex Additive on Properties of Microwave-Hardened and Self- Hardened Moulding Sands with Water Glass
}

\author{
K. Major-Gabryś ${ }^{\mathrm{a} *}$, St. M. Dobosz ${ }^{\mathrm{a}}$, J. Jakubski ${ }^{\mathrm{a}}$, M. Stachowicz ${ }^{\mathrm{b}}$, D. Nowak ${ }^{\mathrm{b}}$ \\ ${ }^{a}$ AGH University of Science and Technology, Faculty of Foundry Engineering, Department of Moulding Materials, Mould \\ Technology and Foundry of Non-ferrous Metals, \\ Al. A.Mickiewicza 30, 30-059 Krakow, Poland \\ ${ }^{\mathrm{b}}$ Foundry and Automation Team, Wroclaw University of Technology, \\ ul. Łukasiewicza 5, 50-371 Wroclaw, Poland \\ *Corresponding author. E-mail address: katmg@agh.edu.pl,
}

Received 01.02.2012; accepted in revised form 17.03.2012

\begin{abstract}
The article takes into consideration the researches concerning inserting the Glassex additive to the microwaved-hardened and selfhardened moulding sands with water glass. In the research different types of ester hardeners to self-hardened moulding sands with water glass were used. The influence of Glassex additive on retained strength of moulding sands with different hardeners and prepared by different technologies of hardening were tested. The influence of different hardeners and the technology of hardening on retained strength of moulding sand with water glass and the Glassex additive were also estimated.
\end{abstract}

Keywords: Moulding sand, Water glass, Ester hardener, Microwave-hardening

\section{Introduction}

Requirements for high castings quality cause scientific investigations leading to obtain moulding and core sands having not only good technological properties, but also being environmental friendly [1-4]. In the Department of Moulding Materials on Faculty of Foundry Engineering AGH (University of Science and Technology) there were investigations taken to elaborate new binding systems based on ecological inorganic binders. The biggest group are the moulding sands with hydrated sodium silicate called moulding sands with water glass. Unfortunately inorganic binder character causes mouldings' low knock-out properties and their low ability to mechanical reclamation. Authors' research on the first stage considered elaborating and patenting moulding sands with new Glassex additive having improved knock-out properties. In the previous publications, authors [5-10] showed that inserting a new additive Glassex to moulding sands with water glass carried out in ester technology improved their knock-out properties defined (measured) according to technological test [5-8] and according to retained strength examination [5, 8-10].

Authors' research proved that microwave hardening lets lowing the binder content what makes their knock-out properties better [11-13].

In this paper the influence of different hardeners and the technology of hardening on bending strength and knock-out properties measured by retained strength investigation of moulding sand with water glass and the Glassex additive. 


\section{Own researches}

\subsection{The investigations of Glassex additive influence on knock-out properties measured by retained strength investigations of moulding sands with water glass and different ester hardeners}

In the article there are presented researches showing the Glassex additive influence on bending strength and knock-out properties of self-hardened moulding sand with water glass and different ester hardeners. Moulding sands with following composition were taken into elaboration:

Quartz sand

Water glass 145

Flodur or ixional SD or jeffsol BC

Glassex

100 parts by weight

3,0 parts by weight

0,3 parts by weight

1,0 part by weight

The results of the experiments are presented in the figures 1-3. The applied research showed that Glassex additive lowers the retained strength of moulding sand with flodur hardener in measured range of temperature and moves the second maximum on the curve into direction of higher temperatures (very rarely existing in foundry moulding sands) were noticed (fig.1). Glassex additive lowers the retained strength of moulding sand with ixional SD hardener in heating temperature of 600 and $800^{\circ} \mathrm{C}$ and moves the second maximum on the curve into direction of higher temperatures were noticed (fig.2). Glassex additive lowers the retained strength of moulding sand with jeffsol $\mathrm{BC}$ hardener in heating temperature of $800^{\circ} \mathrm{C}$ and moves the second maximum on the curve into direction of higher temperatures were noticed (fig.3).

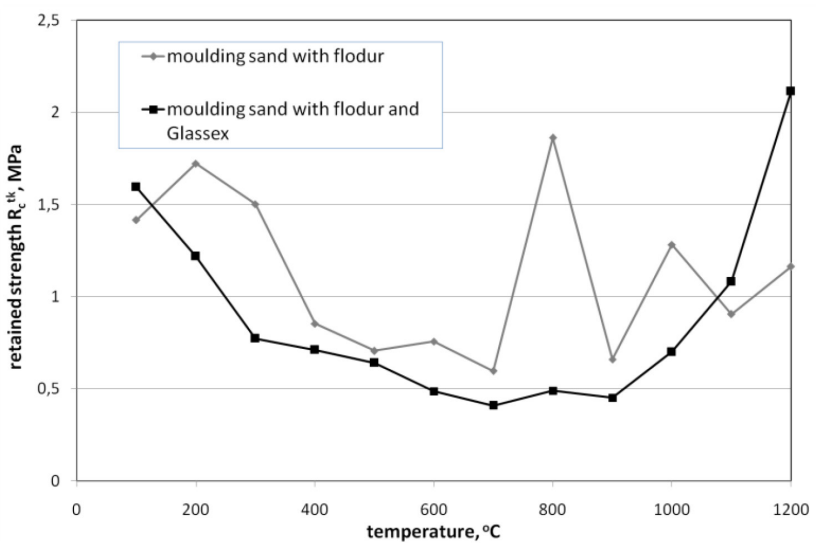

Fig. 1. The influence of Glassex additive on retained strength of moulding sands with water glass hardened with flodur [14]

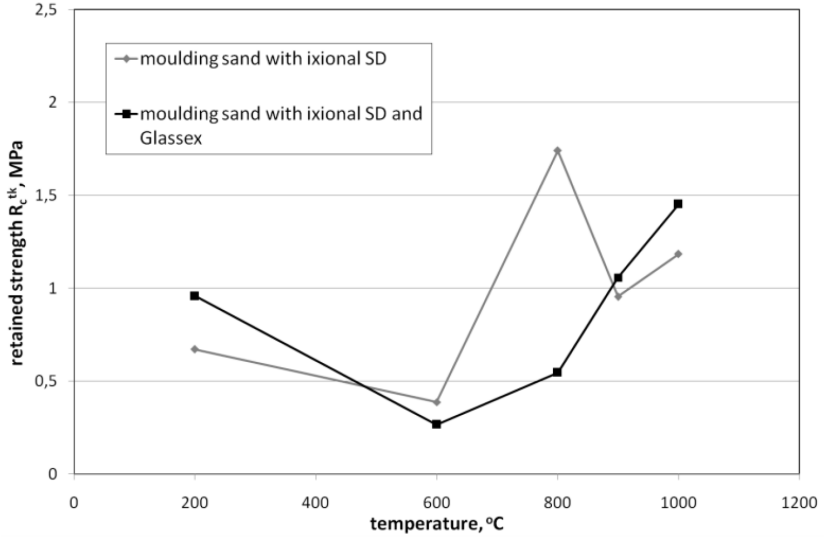

Fig. 2. The influence of Glassex additive on retained strength of moulding sands with water glass hardened with ixional SD [15]

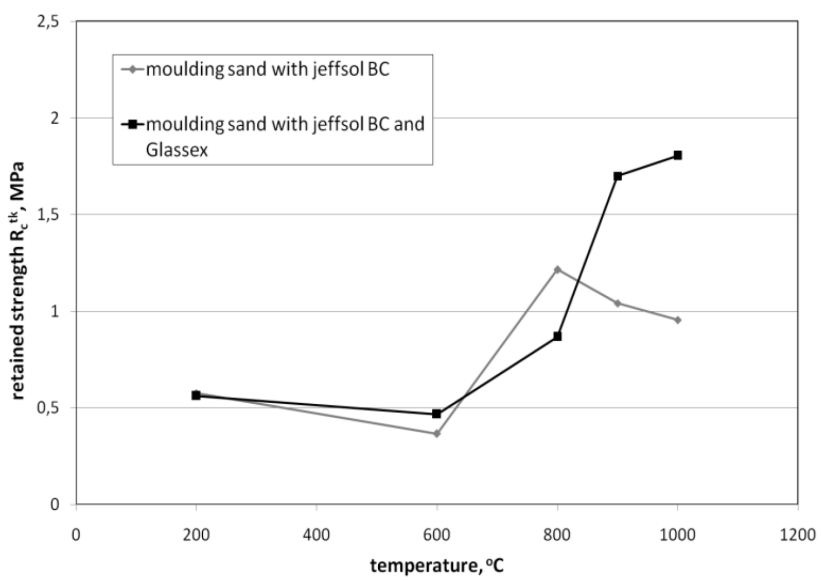

Fig. 3. The influence of Glassex additive on retained strength of moulding sands with water glass hardened with jeffsol BC [15]

\subsection{The investigations of different hardeners and the technology of hardening on bending strength of moulding sand with water glass and the Glassex additive}

Moulding sands with following composition were taken into elaboration:

- $\quad$ microwave-hardened moulding sands

$\begin{array}{lc}\text { Quartz sand } & 100 \text { parts by weight } \\ \text { Water glass } 145 & 2,5-3,5 \text { parts by weight } \\ \text { Glassex } & 1,0 \text { part by weight } \\ \text { Water } & 1,0 \text { part by weight }\end{array}$

The investigations were conducted with using microwave furnace having capacity of 321 with $\max$ power of $1 \mathrm{~kW}$, with microprocessor controlling.

- $\quad$ self-hardened moulding sands
Quartz sand
100 parts by weight
Water glass 145
3,0 parts by weight
Flodur or ixional SD
0,3 parts by weight

or jeffsol BC

Glassex 
The investigations show the influence of type of hardener and type of technology of hardening on bending strength of moulding sands with water glass and Glassex additive. The results of the experiments are presented in the figure 4.

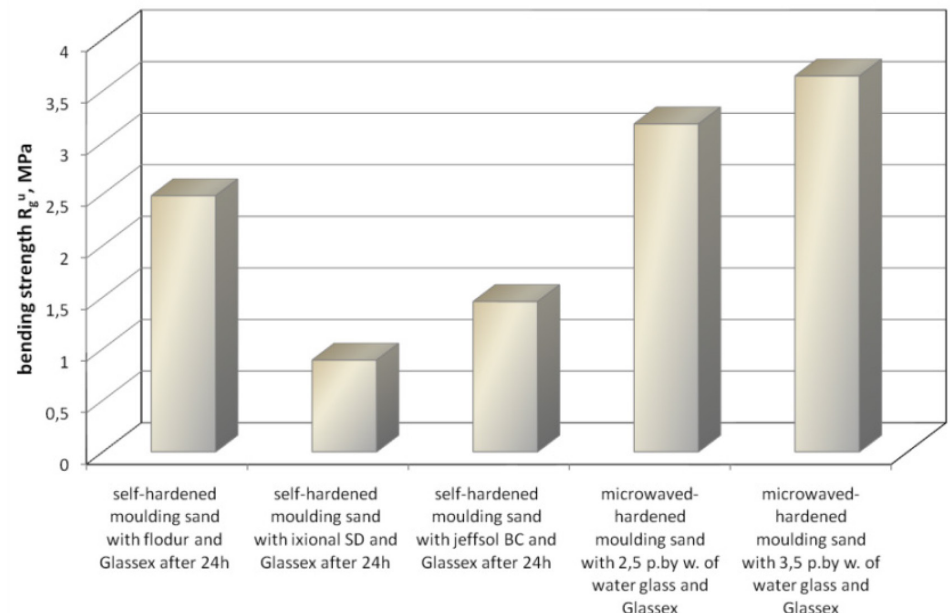

Fig. 4. The influence of different hardeners and the technology of hardening on bending strength of moulding sand with water glass and the Glassex additive

The applied researches showed the influence of hardener type and hardening technology on bending strength of moulding sands with water glass and Glassex additive. Microwaved-hardened moulding sands have better strength properties then self-hardened moulding sands. The worst bending strength has the self-hardened moulding sand with ixional SD hardener.

\subsection{The investigations of different hardeners and the technology of hardening on knock-out properties measured by retained strength investigations of moulding sand with water glass and the Glassex additive}

The knock-out properties of moulding sands were measured by their retained strength investigations. The results of the experiments are presented in the figures 5-8.

The influence of the Glassex additive on retained strength of microwave-hardened moulding sand with water glass is presented in the figures 5-6.

The investigations show that inserting Glassex additive to microwave-hardened moulding sands lowers the retained strength of tested moulding sands in the range of temperature $100-200^{\circ} \mathrm{C}$ and $800-1000^{\circ} \mathrm{C}$ to value below $0,5 \mathrm{MPa}$.

In the figures 7-8 there is shown the influence of different hardeners and the technology of hardening on retained strength of moulding sand with water glass and the Glassex additive.

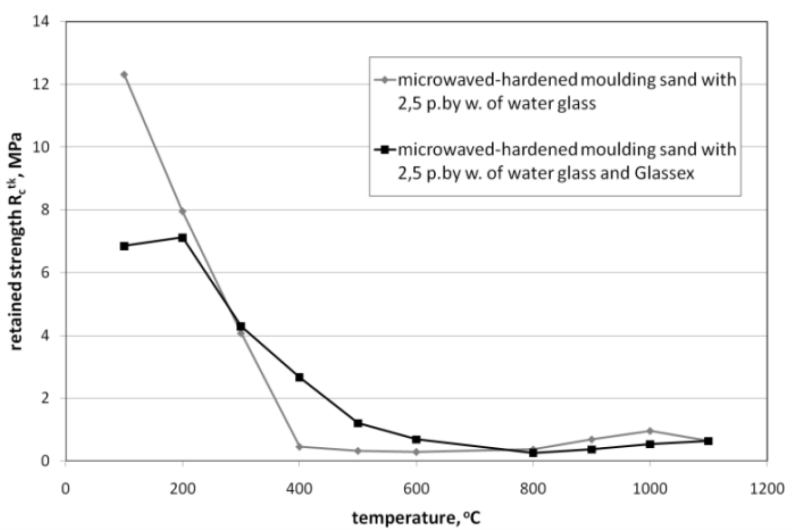

Fig. 5. The influence of Glassex additive on retained strength of microwave-hardened moulding sands with water glass in the temperature range $100-1200^{\circ} \mathrm{C}$

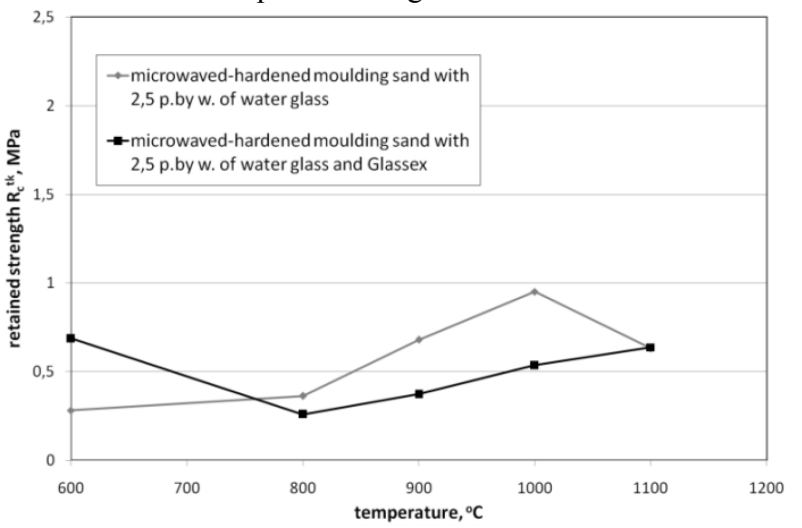

Fig. 6. The influence of Glassex additive on retained strength of microwave-hardened moulding sands with water glass in the temperature range $600-1200^{\circ} \mathrm{C}$ 


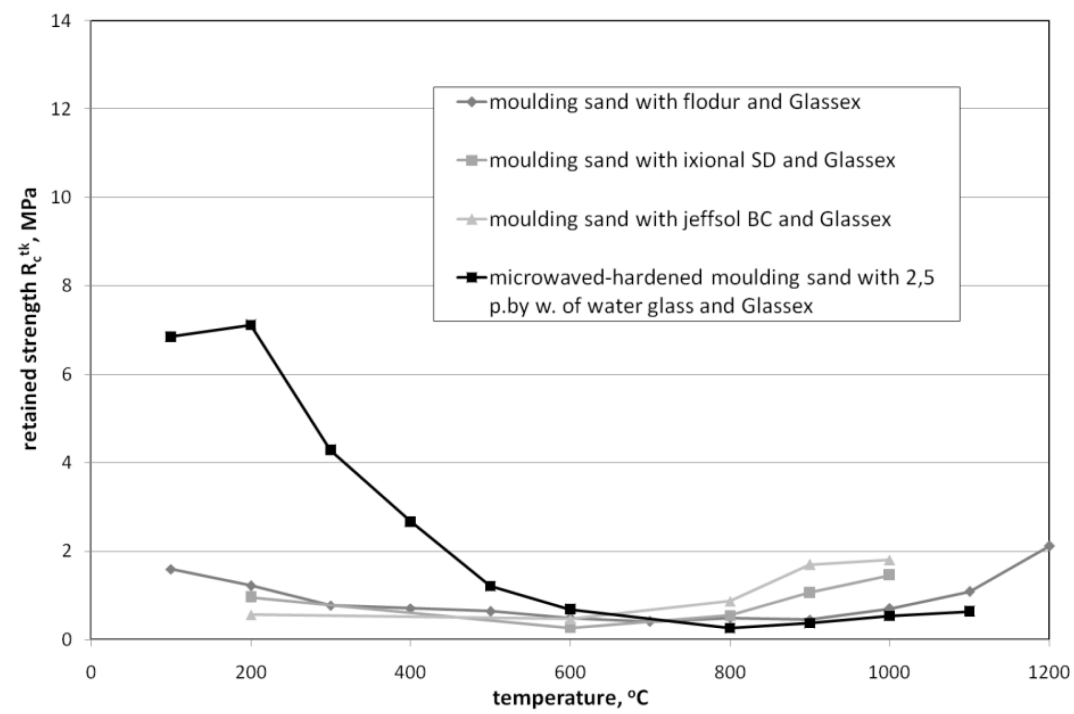

Fig. 7. The influence of different hardeners and the technology of hardening on retained strength of moulding sand with water glass and the Glassex additive in the temperature range $100-1200^{\circ} \mathrm{C}$

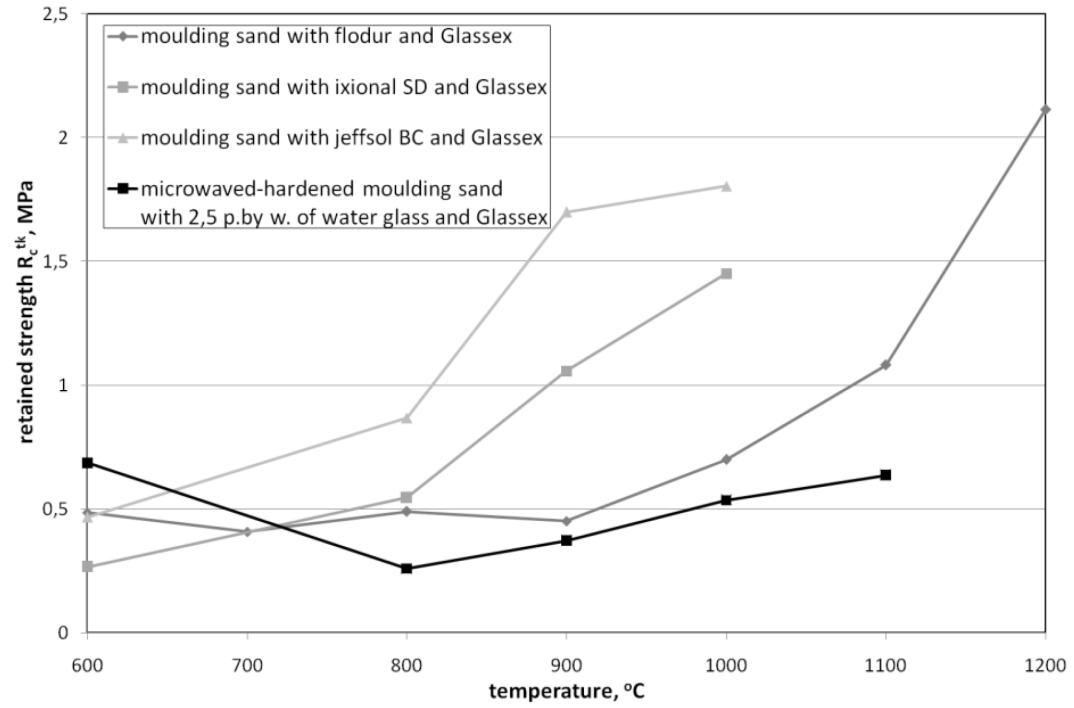

Fig. 8. The influence of different hardeners and the technology of hardening on retained strength of moulding sand with water glass and the Glassex additive in the temperature range $600-1200^{\circ} \mathrm{C}$

The obtained results initially prove that microwave-hardened moulding sand with water glass and Glassex additive has much higher retained strength in the range of temperature $100-500^{\circ} \mathrm{C}$ than self-hardened moulding sands prepared in ester technology with all used types of ester hardeners. In the range of temperature $700-1100^{\circ} \mathrm{C}$ the retained strength of microwave-hardened is lower than retained strength of self-hardened moulding sands with different ester hardeners. The investigations also proved that from self-hardened moulding sands the best knock-out properties has moulding sand with flodur hardener.

\section{Conclusions}

The applied in the article research shows:

- microwave-hardened moulding sands have better strength properties then self-hardened moulding sands. The worst bending strength has the self-hardened moulding sand with ixional SD hardener.

- microwave-hardened moulding sand with water glass and Glassex additive has much higher retained strength in the range of temperature $100-500^{\circ} \mathrm{C}$ than self-hardened moulding sands prepared in ester technology with all used 
types of ester hardeners. In the range of temperature 700$1100^{\circ} \mathrm{C}$ the retained strength of microwave-hardened moulding sand is lower than retained strength of selfhardened moulding sands with different ester hardeners.

In the contest of conducted research it seems proper to use microwave-hardened moulding sands with water glass to core production. High strength properties in ambient temperature and very low retained strength in the range of temperature 700 $1100^{\circ} \mathrm{C}$ makes this environmental friendly moulding sands very interesting from the core production point of view. Core sands are heated to higher temperatures than moulding sands and in the higher range of temperatures retained strength of microwavehardened moulding sands is lower than the retained strength of self-hardened moulding sands. Inserting the Glassex additive to moulding sands with water glass will also increase their knockout properties.

\section{Acknowledgements}

$\begin{array}{cccc}\text { Scientific } & \text { research financed } & \text { from } & \text { AGH, } \\ \text { No } 11.11 .170 .318-3 & \end{array}$

\section{References}

[1] Jelinek, P. (2004). Binding systems of foundry moulding sands. Ostrava. (In Czech).

[2] Baliński A. \& Izdebska-Szanda I. (2004). Influence of morphoactive agents of the soluble sodium silicate on temperature changes in moulding sands with this binder. Archives of Mechanical Technology and Automation. 19-29. (in Polish).

[3] Baliński A., Stechman M. \& Różycka D. (2003). Influence of modification of the soluble sodium silicate with morphoactive agents on the mechanical properties of the moulding sands in temperatures to $900^{\circ} \mathrm{C}$. Materials Engineering. 10 (3), 271-274.

[4] Herecova L. \& Jelinek P. (2006). Esters of carbon acid hardeners for binders based on sodium silicate. Transactions of the VŚB - Technical University of Ostrava. 79-86. (In Czech).
[5] Dobosz St.M. \& Major-Gabryś K. (2003). The new additive to the moulding sands with water glass In DOKSEM (38-41). Słowacja, Rajecke Teplice. (In Polish).

[6] Dobosz St. M. \& Major-Gabryś K. (2003). The new way of upgrading the moulding sand's with water Glass knock-out properties. In Materials of the XXVII Scientific Conference for Foundryman Day, 2003, 81-85, Krakow. (in Polish).

[7] Dobosz St.M. \& Major-Gabryś K. (2004). The surface phenomena in contest of moulding sands' with water Glass knock-out properties. Archives of Mechanical Technology and Automation. 49-56. (In Polish).

[8] Dobosz St.M. \& Major-Gabryś K. (2004). Glassex - The new additive upgrading moulding sand's with water Glass knock-out properties. Archives of Foundry Engineering. 4 (13), 63-68. (In Polish).

[9] Major-Gabryś K. \& Dobosz St.M. (2004). The estimation of knock-out properties of moulding sands with water glass and Glassex additive. In Materials of the XXVIII Scientific Conference for Foundryman Day, 2004, 83-87, Krakow. (In Polish)

[10] Dobosz St.M., Jelinek P. \& Major-Gabryś K. (2011). Development tendencies of moulding and core sands. China Foundry. 8 (4), 438-446.

[11] Stachowicz M., Granat K. \& Nowak D. (2011). Influence of water-glass grade and quantity on residual strength of microwave-hardened moulding sands. Part 1. Archives of Foundry Engineering. 11 (1), 93-98.

[12] Stachowicz M., Granat K. \& Nowak D. (2011). Influence of water-glass grade and quantity on residual strength of microwave-hardened moulding sands. Part 2. Archives of Foundry Engineering. 11 (2), 143-148.

[13] Stachowicz M., Granat K. \& Nowak D. (2011). Influence of $\alpha-\mathrm{Al}_{2} \mathrm{O}_{3}$ on residual strength of microwave-hardened moulding sands with water-glass. Archives of Foundry Engineering. 11 (Special Issue 2), 203-208. (In Polish).

[14] Major-Gabryś K. \& Dobosz St.M. (2010). Self-hardened moulding sands with hydrated sodium silicate and liquid ester hardeners. Polish Metallurgy in 2006-2010 (328-335). Krakow: Committee of Metallurgy of the Polish Academy of Science. (In Polish).

[15] Major-Gabryś K. \& Dobosz St.M. (2011). The influence of Glassex additive on technological properties and knock-out properties of moulding sands with hydrated sodium silicate and new ester hardeners. Metallurgy and Foundry Engineering. 37 (1), 33-40. 